\title{
Ginsenoside from Panax ginseng Meyer Enhances the Cytotoxic and Apoptotic Effect of Cisplatin in A549 Human Lung Cancer Cells
}

\author{
J. K. PARK, V. CASTRO-ACEITUNO, S. AHN, S. Y. SIMU'1 , M. H. SIDDIQI', D. H. KIM, Y. J. KIM AND D. C. YANG ${ }^{1 *}$
}

Department of Oriental Medicinal Biotechnology, ${ }^{1}$ Graduate School of Biotechnology and Ginseng Bank, College of Life Sciences, Kyung Hee University, Yongin, 446 701, Republic of Korea

\section{Park, et al.: Ginsenoside Rf Enhances CPP Effect in Cancer Cells}

Ginsenosides from Panax ginseng Meyer have been used in combination with cisplatin to enhance anticancer potential of cisplatin. However, the combined effects of ginsenoside $R f$ and cisplatin has not been studied so far. Thus, we evaluated the anticancer activity of ginsenoside $R f$ alone and combined with cisplatin by using A549 cell line. Our results showed that cytotoxicity, reactive oxygen species generation and apoptotic effect of cisplatin at $1 \mu \mathrm{g} / \mathrm{ml}$ was enhanced by ginsenoside $R f$ along with the increase of p53 expression at protein and gene level, as well as reduction of the mRNA expression levels of Bcl-2 and Bax was higher for the combined treatment. Further, phosphorylation of epithelial growth factor receptors induced by cisplatin alone was decreased after exposing the cells to the combined treatment. Similarly, the motility of the cells was higher decreased after combining cisplatin and ginsenoside $R f$ than single drug treatment. In this study, ginsenoside $R f$ increased the anticancer effect of cisplatin on A549 cells.

Key words: Panax ginseng; Cisplatin; Apoptosis; EGFR; Lung cancer

Cisplatin is a well-known chemotherapeutic drug used for the treatment of different human cancers, such as the bladder, lung, ovarian, and testicular cancer. The root of cisplatin to induce cytotoxicity in cancer cells has been linked to its ability to interfere with DNA
This is an open access article distributed under the terms of the Creative Commons Attribution-NonCommercial-ShareAlike 3.0 License, which allows others to remix, tweak, and build upon the work non-commercially, as long as the author is credited and the new creations are licensed under the identical terms

Accepted 19 April 2017

Revised 04 January 2017

Received 14 July 2016

Indian J Pharm Sci 2017;79(3):468-474 
repair mechanism and with this induce DNA damage in cancer cells ${ }^{[1,2]}$. However, several studies reported drug resistance and several side effects observed in patients during the treatment ${ }^{[1]}$. Among this, the search for new therapeutic agents with the capability to decrease the side effects and overcome the drug-resistance of cisplatin has been increasing over the years.

Over the years, numerous natural compounds had been used as anticancer therapeutic agents ${ }^{[3]}$. Panax ginseng Meyer, a traditional herbal medicine used for thousands of years in East Asian countries, showed a variety of anticancer properties in several studies ${ }^{[4]}$. Ginsenosides isolated from $P$. ginseng, have been reported to enhance the anticancer activity of cisplatin ${ }^{[5]}$. However, the activity of the unique ginsenoside $\mathrm{Rf}(\mathrm{Rf})$, isolated only from $P$. ginseng root, and its interaction with cisplatin has not been reported so far. Previously, Rf has demonstrated to induce $\mathrm{G} 2 / \mathrm{M}$ phase cell cycle arrest and apoptosis in human osteosarcoma, MG-63 cell line, through the mitochondrial pathway ${ }^{[6]}$. Thus, we hypothesize that $\mathrm{Rf}$ alone might have an effect on cell motility, induces cytotoxicity and apoptosis, as well as enhanced the anticancer activity of cisplatin in A549 lung cancer cells.

The ginsenoside Rf, a unique compound from $P$. ginseng; was received from ginseng bank, Kyung Hee University (South Korea) in powdered with a purity of $\geq 95 \%$. Cisplatin (Platosin) was obtained at $1 \mathrm{mg} / \mathrm{ml}$ from Pharmachemie B. V. (GA, Netherlands). RPMI-1640 culture media was purchased from GenDEPOT Inc. (TX, USA). Fetal bovine serum (FBS) and the antibiotics, $100 \mathrm{UI} / \mathrm{ml}$ penicillin and $100 \mu \mathrm{g} / \mathrm{ml}$ streptomycin, from Gibco-Brl (MD, USA).

Non-small lung carcinoma cells (A549), were obtained from Korean Cell Line Bank (Seoul, South Korea). The cells were grown in RPMI-1640, supplemented with $10 \%$ FBS and $1 \%$ of antibiotics. The cells were maintained in an incubator at $37^{\circ}$ with a humidified atmosphere of $5 \% \mathrm{CO}_{2}$. The evaluation of cell toxicity was done by MTT (3,4,5-dimethylthiazol-2-yl)-2-5diphenyletrazolium bromide) assay. The cells were exposed to cisplatin $(1 \mu \mathrm{g} / \mathrm{ml})$ in the presence or absence of ginsenoside $\mathrm{Rf}$ for $72 \mathrm{~h}$. Ten microlitres of MTT assay solution $(5 \mathrm{mg} / \mathrm{ml})$ was added to each well and incubated for $3 \mathrm{~h}$ after the treatment had finished. Then, old media was replaced by $100 \mu 1$ of DMSO and incubated for $30 \mathrm{~min}$. The amount of formazan formed by viable cells was measured by a multi-model plate reader (Bio-Tek Instrument, Winooski, VT) at a test wavelength of $570 \mathrm{~nm}$ with a reference wavelength of $630 \mathrm{~nm}^{[7]}$. All experiments were repeated in triplets.

A549 cells were cultured in a 12 -well plate $\left(2.5 \times 10^{5}\right.$ cells per well) and incubated for $24 \mathrm{~h}$ at $5 \% \mathrm{CO}_{2}$ and $37^{\circ}$ humidified atmosphere. After a complete confluence was reached, old medium was replaced with serum-free growth media for $24 \mathrm{~h}$. Then, a $10 \mu \mathrm{l}$ sterile pipette tip was used to make a scratch in A549 cell cultures layer. In order to remove dead or floating cells, each well was washed twice with PBS. The cells were stimulated with epidermal growth factor (EGF, $20 \mathrm{ng} / \mathrm{ml}$ ) and treated according to our schedule: $2 \% \mathrm{FBS}$, $2 \% \mathrm{FBS}+\mathrm{EGF}, 2 \% \mathrm{FBS}+\mathrm{EGF}+$ cisplatin $1 \mu \mathrm{g} / \mathrm{ml}, 2 \%$ $\mathrm{FBS}+\mathrm{EGF}+\mathrm{Rf} 100 \mu \mathrm{M}$ and $2 \% \mathrm{FBS}+\mathrm{EGF}+$ cisplatin $1 \mu \mathrm{g} / \mathrm{ml}+\mathrm{Rf} 100 \mu \mathrm{M}$. The scratch gap width at $24 \mathrm{~h}$ in each treatment group was measured at two different positions and compared to the gap width at $0 \mathrm{~h}$. The analysis of the images, taken at x10 under an optical microscope Eclipse ME600L (Nikon Instruments, Melville, NJ), was done by T-scratch program ${ }^{[8]}$. The motility of the cells in response to the treated cells was determined relative to the EGF vehicle control.

A549 cells were exposed to cisplatin $(1 \mu \mathrm{g} / \mathrm{ml})$ in the presence or absence of ginsenoside $\operatorname{Rf}(100 \mu \mathrm{M})$ for $48 \mathrm{~h}$. Cells were washed twice with 1x PBS and fixed with $3.7 \%(\mathrm{v} / \mathrm{v})$ formaldehyde for $5 \mathrm{~min}$ at room temperature and washed twice with PBS. In order to dye the nucleus, the cells were stained with Hoechst 33258 solution $(2 \mu \mathrm{g} / \mathrm{ml})$ for $30 \mathrm{~min}$ in dark condition at room temperature. Nuclear morphologies of the Hoechst-positive cells were observed and photographed under a fluorescence microscope (x400, Optinity, Korean Labtech) for further analysis.

Total RNA was isolated from cultured cells using TriZol LS reagents (Invitrogen, Carlsbad, CA, USA) according to the manufacturer's protocol. The firststrand cDNAs was synthesized by using Thermo Scientific cDNA synthesis kit (Onebio, Lithuania $\mathrm{EU})^{[9,10]}$. Initial denaturation at $95^{\circ}$ for $3 \mathrm{~min}$ followed by a PCR cycle of denaturation at $95^{\circ}$ for $45 \mathrm{~s}$, annealing at $58^{\circ}$ for $1 \mathrm{~min}$ and strand extension at $72^{\circ}$ for $1 \mathrm{~min}$. The number of cycles was 30 . The final step included incubation at $72^{\circ}$ for $10 \mathrm{~min}$. The resultant PCR products were electrophoresed on a $0.8 \%$ agarose gel and analyzed with Image $\mathrm{J}$ software ${ }^{[11]}$. SYBR Green qPCR Super Mix UDG kit (Invitrogen, Carlsbad, CA) was used for quantitative real-time polymerase chain reaction (qRT-PCR) amplification 
in a R-Corbett Rotor-Gene Model 6000 (Mortlake, NSW 2137, Australia). Amplifications were performed at an initial temperature of $95^{\circ}$ for $10 \mathrm{~min}$, followed for 40 cycles at $95^{\circ}$ for $10 \mathrm{~s}, 60^{\circ} 15 \mathrm{~s}$, and $72^{\circ}$ for $20 \mathrm{~s}$. The analysis was done by follow the delta cycle threshold (Ct) method.

Cells were plated at a density of $1 \times 10^{4}$ cells per wells in 96 well plate, allowed to attach overnight and exposed to treatment for $72 \mathrm{~h}$. The cells were stained with $10 \mu \mathrm{M} \mathrm{H}_{2} \mathrm{DCFDA}$ for $30 \mathrm{~min}$ at $37^{\circ}$, and the fluorescence intensity of the cells was determined using multi-model plate reader.

A549 cells were seeded in $100 \mathrm{~mm}$ dish culture plate at $5 \times 10^{6}$ cells per dish. After $24 \mathrm{~h}$ incubation, the cells were subject to serum starvation for $20 \mathrm{~h}$ following by $48 \mathrm{~h}$ of treatment. External EGF stimulation was done at $20 \mathrm{ng} / \mathrm{ml}$ for $30 \mathrm{~min}$ prior protein isolation. After stimulation and the treatment time was finished, the cells were rinsed twice with ice-cold PBS. The total proteins were solubilized with $2 \mathrm{X}$ sodium dodecyl sulphate (SDS) loading buffer $(100 \mathrm{mM}$ Tris-Cl $(\mathrm{pH} 6.8), 4 \%(\mathrm{w} / \mathrm{v})$ SDS, 0.2\% (w/v) bromophenol blue, $20 \%$ glycerol and $200 \mathrm{mM} \beta$-mercaptoethanol) for $5 \mathrm{~min}$ at room temperature (RT). Then, the protein was denatured at $95^{\circ}$ for $10 \mathrm{~min}$ and storage at $-20^{\circ[12]}$.

For immunoblotting, proteins of total cell lysates were loaded and resolved in 10\% SDS-polyacrylamide gel electrophoresis and run at $120 \mathrm{~V}$. The proteins were then transferred to nitrocellulose membranes (Millipore) at $100 \mathrm{~V}$ for $2 \mathrm{~h}$. The membranes were blocked at room temperature (RT) for $1 \mathrm{~h}$ with $5 \%$ skim milk. After blocking, the blots were incubated with specific antibodies (Phospho-EGF Receptor (Tyr1068), EGF receptor, p53, and $\beta$-actin) overnight at $4^{\circ}$. The blots were then washed seven times with TBS-T, followed by goat antimouse or antirabbit IgG secondary antibody for $2 \mathrm{~h}$ at RT. Immunolabelling was visualized by enhanced chemiluminescence detection (EMD Millipore). Band densities were measured using ImageJ software ${ }^{[1]}$.

The statistical analyses were performed using GraphPad 6.04 software (La Jolla, CA 92037, USA). Results are expressed as mean $\pm \mathrm{SEM}$. The statistical significance of differences between values was evaluated by one-way ANOVA. The differences were considered significant at $\mathrm{P} \leq 0.05$.

In the present study, we investigate the ability of ginsenoside $\mathrm{Rf}(\mathrm{Rf})$ to increase the anticancer activity of cisplatin. The effect was associated with the inhibition of cell growth, cell motility; and induction of apoptosis at in vitro level. Previously, was reported the ability of compounds derived from medicinal plants to enhance the cytotoxicity of cisplatin in A549 lung cancer cells ${ }^{[13]}$. Furthermore, it had been reported that ginsenosides from $P$. ginseng enhanced the anticancer activity of cisplatin ${ }^{[13,14]}$. In this study, as a result of the treatment with Rf at $100 \mu \mathrm{M}$ in the presence of cisplatin at $1 \mu \mathrm{g} / \mathrm{ml}$, a significant reduction in the cell viability compared to individual $\mathrm{Rf}$ and cisplatin treatments was observed (fig. 1). In addition, the combined treatment significantly enhanced the ROS generation compared to the individual treatments (fig. 2). This result indicated that ginsenoside Rf may enhance the cytotoxicity of cisplatin through increasing the generation of reactive oxygen species.

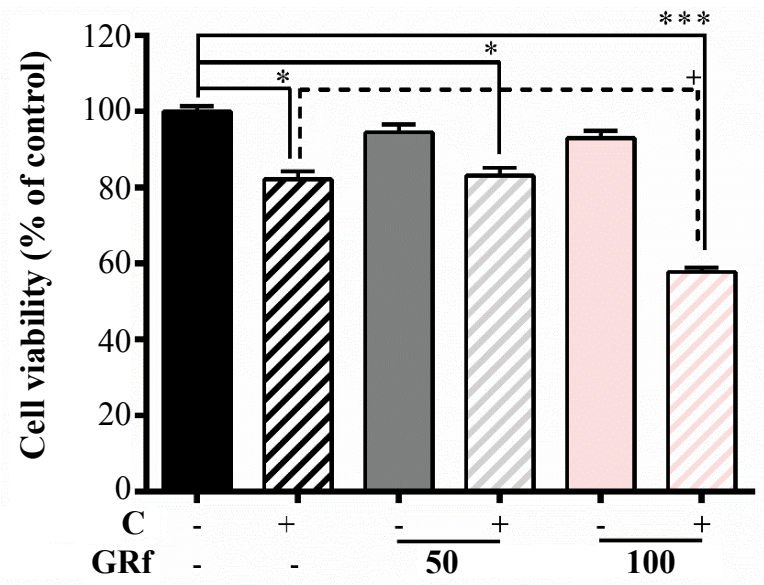

Fig. 1: Cytotoxicity and pharmacological interaction of ginsenoside $R f$ and cisplatin

Results are representative of three independent experiments. Data are shown as mean \pm SEM. $* * * \mathbf{P}<0.05$ vs. control. $* \mathbf{P}<0.05$ vs. cisplatin alone. $G$ Rf: Ginsenoside $R f(\mu M)$ and $C$ : cisplatin $(1 \mu \mathrm{g} / \mathrm{ml})$

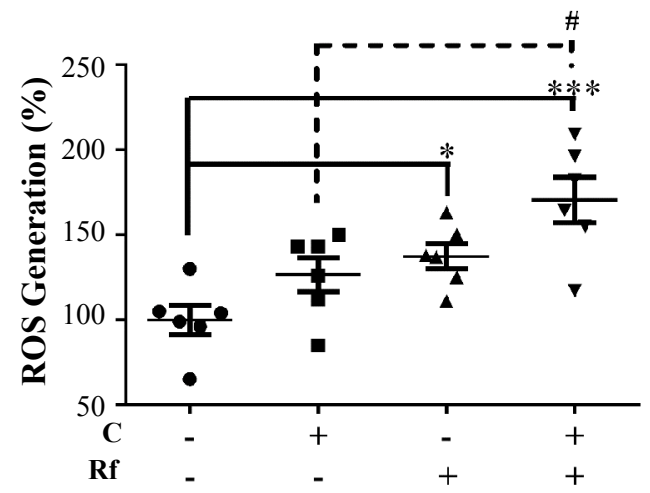

Fig. 2: Intracellular ROS generation induced by ginsenoside Rf and cisplatin

The production of intracellular ROS in treated A549 cells was detected by using H2DCFDA. Data are shown as mean \pm SEM. ${ }^{* * *} \mathrm{P}<0.05$ vs. control. \#P<0.05 vs. cisplatin alone. ROS: reactive oxygen species; $R f$ : ginsenoside $R f(100 \mu M)$ and C: cisplatin $(\mu \mathrm{g} / \mathrm{ml})$ 
Theinduction of apoptosis by cisplatin through induction of DNA damage had been well documented ${ }^{[15,16]}$. Besides, the induction of apoptosis by $\mathrm{Rf}$ in osteosarcoma cells had been already reported ${ }^{[1,15-17]}$. Thus, in order to determinate whether the cytotoxicity of the combined treatment of Rf and cisplatin can be related to the induction of apoptosis, we evaluated the effect of the single and combined treatment on the

a

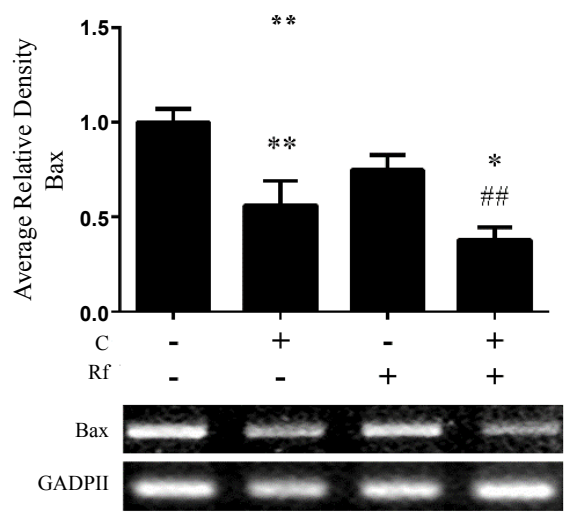

expression of apoptotic markers as well as evaluate its effect on the nucleus morphology. A higher reduction in mRNA expression levels of Bax (fig. 3a) and Bcl-2 (fig. 3b) was observed in the combined treatment group than the single ones. In addition, highly number of apoptotic cells was observed in the present of cisplatin and RF than these drugs alone (fig. 4a). Further, protein expression analysis of $\mathrm{p} 53$ protein showed a b

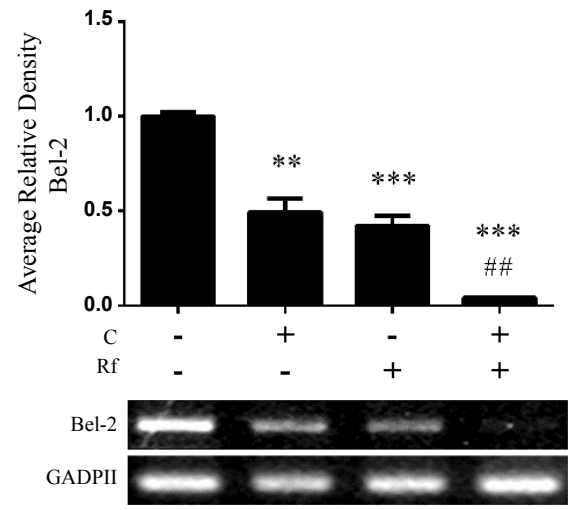

Fig. 3: Expression of pro- and antiapoptosis genes in A549 cells

The density of PCR bands of relative gene expression of apoptotic genes was done by ImageJ software. Data are shown as mean \pm SEM. ${ }_{* * *} \mathbf{P}<0.05$ vs. control. Rf: ginsenoside $(100 \mu \mathrm{M})$; C: cisplatin $(1 \mu \mathrm{g} / \mathrm{ml})$

a

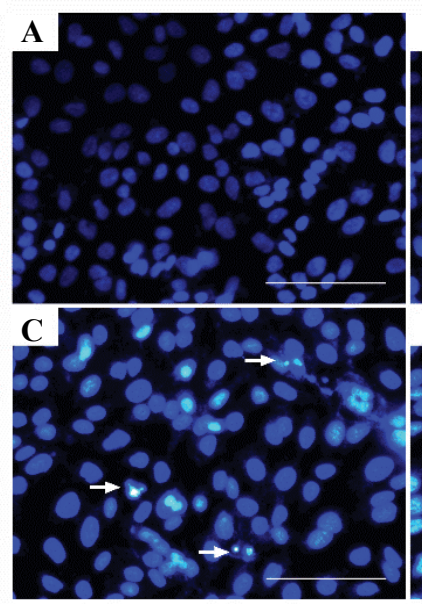

C

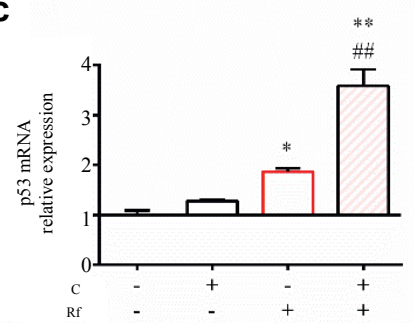

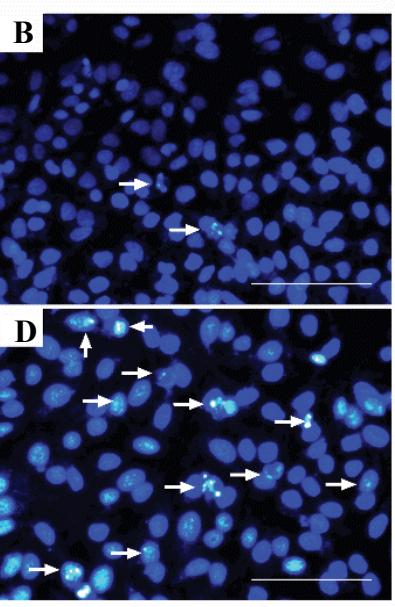

d

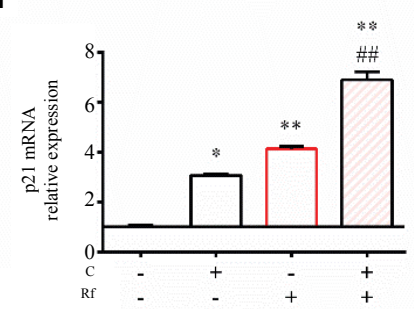

b

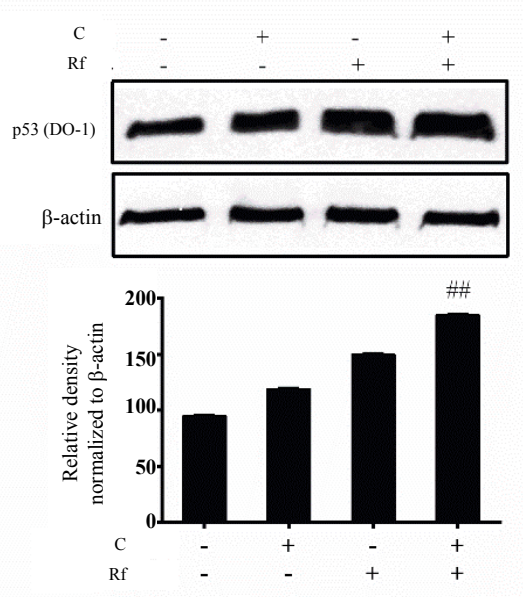

e

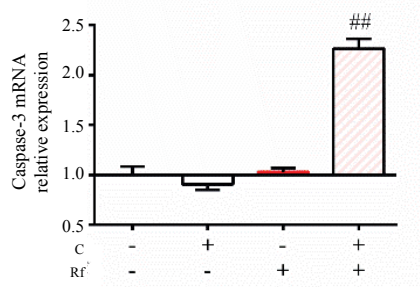

Fig. 4: Analysis of apoptotic activity of the single and combined drug treatment in A549 cells

(a) Morphological changes in the nucleus were observed by Hoechst 33258 assay after the following treatment: A. untreated cells, B. $\mathrm{Rf}$ at $100 \mu \mathrm{M}$, C. cisplatin at $1 \mu \mathrm{g} / \mathrm{ml}$ and $\mathrm{D}$. cisplatin at $1 \mu \mathrm{g} / \mathrm{ml}+\mathrm{Rf}$ at $100 \mu \mathrm{M}$. Apoptotic cells are indicated with arrows. Scale bar: $10 \mu \mathrm{m}$. (b) Western blot analysis of expression of the pro-apoptotic p53 protein. (c-e) mRNA expression analysis of apoptotic related genes normalized to GAPDH. Results are representative of three independent experiments. Data are shown as mean \pm SEM. ${ }^{\star \star P}<0.05$ vs. control. ${ }^{\# \#} \mathrm{P}<0.05$ vs. cisplatin alone. Rf: ginsenoside $(100 \mu \mathrm{M})$; C: cisplatin $(1 \mu \mathrm{g} / \mathrm{ml})$ 
significant increase in the presence of the combined treatment (fig. 4b). Also, mRNA expression of p53, p21 and caspase 3 genes was higher in the combined group (fig. 4c-e). In previous studies, was reported that the genes, Bcl-2 and Bax, can be capable of independent regulation of a common apoptotic pathway ${ }^{[18]}$. Besides, some studies indicated that a decrease in the expression levels of Bax is associated with cisplatin resistance and Mutation of $\mathrm{p} 53$ gene $^{[19]}$. This mutation of the $\mathrm{p} 53$ gene was previously reported in A549 cells ${ }^{[20]}$. For this reason, we suggest that the independent regulation of Bax and Bcl-2 genes and increase in the pro-apoptotic markers in A549 cells observed during the combined treatment with Rf and cisplatin might be involved in the induction of morphological changes of the nucleus visualized through Hoechst 33258 staining.

The activation of epithelial growth factor receptors (EGFR) by cisplatin had been reported previously ${ }^{[21]}$. This phosphorylation of EGFR leads to the activation of different pathways and with this the initiation of other processes, such as migration and invasion ${ }^{[22]}$. Since metastasis represent the major problem in the treatment of cancer and involves multiple processes such cell migration ${ }^{[23]}$, evaluation of the ability of the combined treatment with Rf and cisplatin to reduce the phosphorylation of EGFR and cell migration was evaluated. It was found that $\mathrm{Rf}$ (alone) did not modify the expression of phospho-EGFR. On the other hand, the combined treatment with $\mathrm{Rf}$ and cisplatin reduced the expression of phospho-EGFR previously enhanced by cisplatin (fig. 5). Also, was observed that the combined drug treatment induces a higher decreased on cell migration than single drug treatment (fig. 6a and b). Next, in order to define if the scratch assay result were related to cell migration and not to the, evaluation of mRNA levels of cadherin, snail and slug genes, which are related to epithelialmesenchymal transition (EMT) process because of its relation to wound healing and cancer progression ${ }^{[24]}$. Our results have shown the increase in the expression of e-cadherin gene (fig. 6c) and the decrease of snail and slug genes (fig. 6d-e) for the combined drug treatment, this effect was significantly different in comparison with the cisplatin treatment alone. This finding suggested an antimigratory activity of $\mathrm{Rf}$ in the presence of cisplatin though a possible shift of motile mesenchymal cells, EGF-stimulated A549 cells; into epithelial cells.

This study exposed for the first time the effect of a

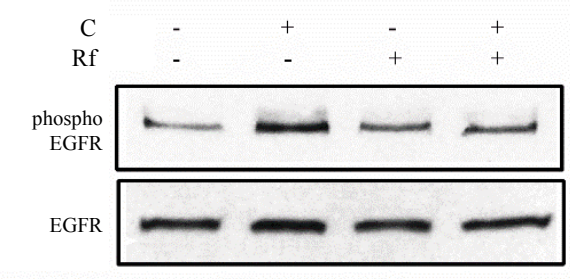

b

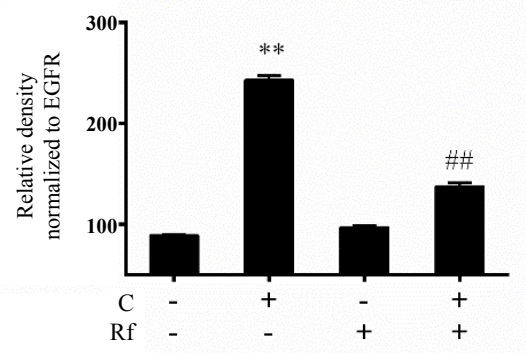

c

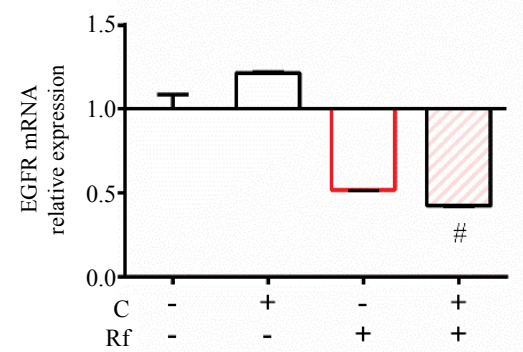

Fig. 5: Analysis of epithelial growth factor receptor (EGFR) pathway

(a) Immunoblotting of phospho-EGFR and EGFR proteins in presence or absence of treatment. (b) Density analysis of PCR bands was done by Image $J$ software. (c) mRNA expression of EGFR gene normalized to GAPDH. Data are shown as mean \pm SEM. ${ }^{\star \star} \mathrm{P}<0.05$ vs. control. $\mathrm{Rf}$ : ginsenoside $(100 \mu \mathrm{M})$; $\mathrm{C}$ : cisplatin $(1 \mu \mathrm{g} / \mathrm{ml})$

ginsenoside $\mathrm{Rf}(\mathrm{Rf})$ in the combination of cisplatin against A549 a lung-carcinoma cell line. It was observed that $\mathrm{Rf}$ at $100 \mu \mathrm{M}$ enhanced the cytotoxicity, apoptotic and the effect on cell motility of cisplatin at $1 \mu \mathrm{g} / \mathrm{ml}$. It is envisaged that further studies are needed by the use of other cancer cell lines to determinate whether the effect is observed in other cancer cells or if is specific to A549 lung cancer cells.

\section{Conflict of interest:}

The authors report no declarations of interest.

\section{Acknowledgements:}

This work was supported by the Korea Institute of Planning and Evaluation for Technology in Food, Agriculture, Forestry and Fisheries, Republic of Korea (grant number 313038-03-2-SB010).

\section{Financial support:}

Nil. 


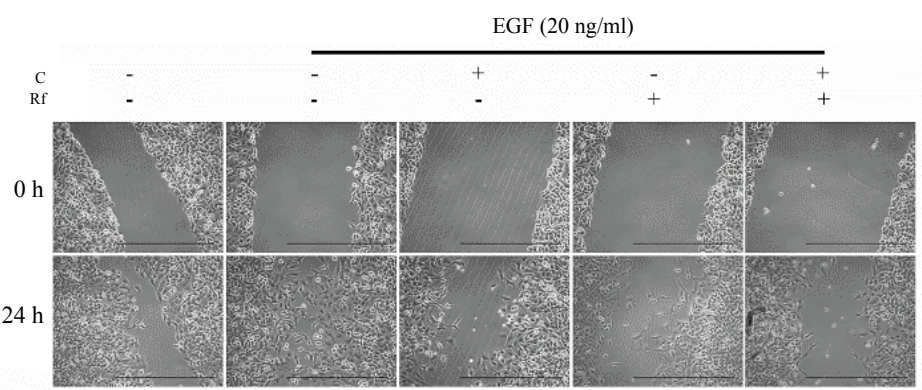

c

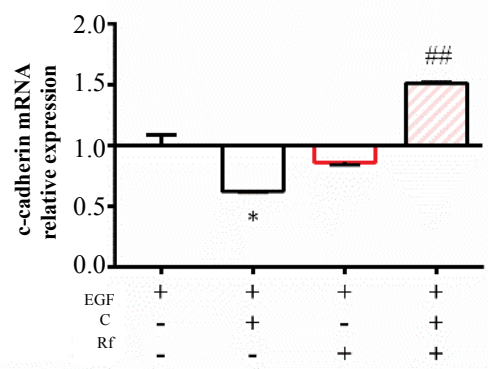

d

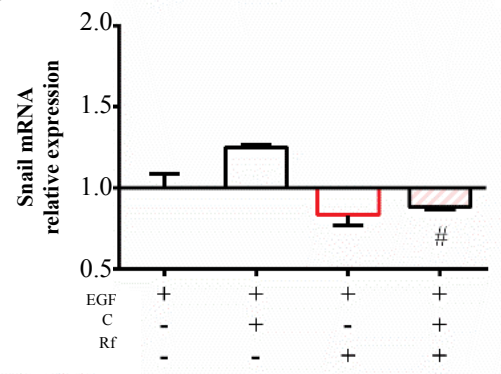

b

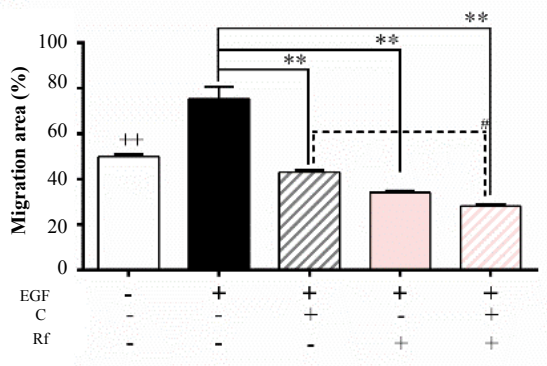

$\mathbf{e}$

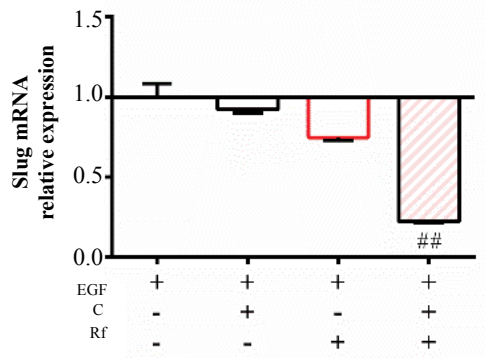

Fig. 6: Ginsenoside $\mathrm{Rf}$ and cisplatin reduce cell migration in A549 cells

(a) Photographs of A549 cells were taken at the beginning of the scratch assay and after $24 \mathrm{~h}$. Scale bar: $50 \mu \mathrm{m}$. (b) Percentage of the scratch gap width after $24 \mathrm{~h}$. (c-e) Evaluation of the mRNA levels for epithelial and mesenchymal genes. Each column represents the mean \pm SEM. ${ }^{++} \mathbf{P}<0.05$ Control versus EGF-Control. ${ }^{*} \mathrm{P}<0.05$ versus EGF-control. ${ }^{\# *} \mathrm{P}<0.05$ versus cisplatin alone. EGF: epidermal growth factor $(20 \mathrm{ng} / \mathrm{ml})$; Rf: ginsenoside $(100 \mu \mathrm{M})$; C: cisplatin $(1 \mu \mathrm{g} / \mathrm{ml})$

\section{REFERENCES}

1. Dasari S, Tchounwou PB. Cisplatin in cancer therapy: molecular mechanisms of action. Eur J Pharmacol 2014;740:364-78.

2. Kelland L. The resurgence of platinum-based cancer chemotherapy. Nat Rev Cancer 2007;7:573-84.

3. Murthy KNC, Sultanpur CM, Rao RM. Natural molecules as tumour inhibitors: Promises and prospects. J Herb Med 2014; 4:175-87.

4. Leung KW, Wong AS. Pharmacology of ginsenosides: a literature review. Chin Med 2010;5:20.

5. Chen S, Wang Z, Huang Y, O'Barr SA, Wong RA, Yeung S, et al. Ginseng and anticancer drug combination to improve cancer chemotherapy: a critical review. Evid Based Complement Alternat Med 2014;2014:168940.

6. Xu X, Zhang Y, Qu D, Jiang T, Li S. Osthole induces G2/M arrest and apoptosis in lung cancer A549 cells by modulating PI3K/Akt pathway. J Exp Clin Cancer Res 2011;30:33.

7. Ahn S, Siddiqi MH, Aceituno VC, Simu SY, Zhang J, Perez $\mathrm{ZE}$, et al. Ginsenoside Rg5: Rk1 attenuates TNF- $\alpha / \mathrm{IFN}-$ $\gamma$-induced production of thymus-and activation-regulated chemokine (TARC/CCL17) and LPS-induced NO production via downregulation of NF- $\mathrm{KB} / \mathrm{p} 38$ MAPK/STAT1 signaling in human keratinocytes and macrophages. In Vitro Cell Dev Biol Anim 2016;52:287-95.

8. Gebäck T, Schulz MM, Koumoutsakos P, Detmar M. TScratch: a novel and simple software tool for automated analysis of monolayer wound healing assays. Biotechniques 2009;46:265-74.

9. Ahn S, Siddiqi MH, Noh HY, Kim YJ, Kim YJ, Jin CG, et al. Antiinflammatory activity of ginsenosides in LPS-stimulated RAW 264.7 cells. Science Bulletin 2015;60:773-84.
10. Siraj FM, Natarajan S, Huq MA, Kim YJ, Yang DC. Structural investigation of ginsenoside Rf with PPAR $\gamma$ major transcriptional factor of adipogenesis and its impact on adipocyte. J Ginseng Res 2015;39:141-7.

11. Collins TJ. ImageJ for microscopy. Biotechniques 2007;43:25-30.

12. Dubon MJ, Park KS. Substance P enhances the proliferation and migration potential of murine bone marrow-derived mesenchymal stem cell-like cell lines. Exp Ther Med 2015;9:1185-91.

13. Ozturk O, Bozcuk H, Burgucu D, Ekinci D, Ozdogan M, Akca $\mathrm{S}$, et al. Cisplatin cytotoxicity is enhanced with zoledronic acid in A549 lung cancer cell line: preliminary results of an in vitro study. Cell Biol Int 2007;31:1069-71.

14. Li Y, Zhou T, Ma C, Song W, Zhang J, Yu Z. Ginsenoside metabolite compound $\mathrm{K}$ enhances the efficacy of cisplatin in lung cancer cells. J Thorac Dis 2015;7:400-6.

15. Arany I, Megyesi JK, Kaneto H, Price PM, Safirstein RL. Cisplatin-induced cell death is EGFR/src/ERK signaling dependent in mouse proximal tubule cells. Am J Physiol Renal Physiol 2004;287:F543-F9.

16. Sorenson CM, Eastman A. Mechanism of cisdiamminedichloroplatinum (II)-induced cytotoxicity: role of G2 arrest and DNA double-strand breaks. Cancer Res 1988;48:4484-8.

17. Shangguan WJ, Li H, Zhang YH. Induction of G2/M phase cell cycle arrest and apoptosis by ginsenoside $\mathrm{Rf}$ in human osteosarcoma MG-63 cells through the mitochondrial pathway. Oncol Rep 2014;31:305-13.

18. Chao DT, Korsmeyer SJ. BCL-2 family: regulators of cell death. Annu Rev Immunol 1998;16:395-419.

19. Perego P, Giarola M, Righetti SC, Supino R, Caserini C, 
Delia D, et al. Association between cisplatin resistance and mutation of $\mathrm{p} 53$ gene and reduced bax expression in ovarian carcinoma cell systems. Cancer Res 1996;56:556-62.

20. Supino R, Perego P, Gatti L, Caserini C, Leonetti C, Colantuono $\mathrm{M}$, et al. A role for c-myc in DNA damage-induced apoptosis in a human TP53-mutant small-cell lung cancer cell line. Eur J Cancer 2001;37:2247-56.

21. Benhar M, Engelberg D, Levitzki A. Cisplatin-induced activation of the EGF receptor. Oncogene 2002;21:8723-31.
22. Ciardiello F, De Vita F, Orditura M, Tortora G. The role of EGFR inhibitors in nonsmall cell lung cancer. Curr Opin Oncol 2004;16:130-5.

23. Kramer N, Walzl A, Unger C, Rosner M, Krupitza G, Hengstschläger $\mathrm{M}$, et al. In vitro cell migration and invasion assays. Mutat Res 2013;752:10-24.

24. Lamouille S, Xu J, Derynck R. Molecular mechanisms of epithelial-mesenchymal transition. Nat Rev Mol Cell Biol 2014; $15: 178$. 